\title{
Temporal partitioning: dynamics of alternating occupancy of a host microhabitat by two different crustacean parasites
}

\author{
Susumu Ohtsuka ${ }^{1, *}$, Shinsuke Harada ${ }^{1}$, Michitaka Shimomura ${ }^{2}$, \\ Geoffrey A. Boxshall ${ }^{3}$, Reiko Yoshizaki ${ }^{1}$, Daisuke Ueno ${ }^{1}$, Yusuke Nitta ${ }^{1}$, \\ Sadaharu Iwasaki ${ }^{1}$, Hiroko Okawachi ${ }^{1}$, Tadashi Sakakihara ${ }^{1}$ \\ ${ }^{1}$ Takehara Marine Science Station, Setouchi Field Centre, Graduate School of Biosphere Science, Hiroshima University, \\ 5-8-1 Minato-machi, Takehara, Hiroshima 725-0024, Japan \\ ${ }^{2}$ Kitakyushu Museum of Natural History and Human History, 2-4-1 Higashida, Yahatahigashi-ku, Kitakyushu, \\ Fukuoka 805-0071, Japan \\ ${ }^{3}$ Department of Zoology, The Natural History Museum, Cromwell Road, London SW7 5BD, UK
}

\begin{abstract}
Double infection by 2 crustacean parasites was found on the mysid Siriella okadai collected from the Seto Inland Sea, Japan. An epicaridean isopod, Prodajus curviabdominalis, and a siphonostomatoid copepod, Neomysidion rahotsu, both occupied the lumen of the host marsupium, and fed voraciously upon host eggs. Interestingly, adult females of these 2 parasites occurred alternately on the host, with almost no overlap: the copepod occurred from mid-winter to summer when water temperatures were $<20^{\circ} \mathrm{C}$ (with mean prevalence of $7.2 \%$ ), whereas the isopod occurred exclusively from midsummer to late autumn when water temperatures exceeded $20^{\circ} \mathrm{C}$ (with mean prevalence of $9.1 \%$ ). Possible factors responsible for generating and maintaining this alternation of microhabitat occupancy on the host are discussed on the basis of the life cycles and host-specificities of the 2 parasites. In addition, we explored the possible means by which these obligate parasites survive during the periods when they are not on the mysid host. In the case of the isopod, we hypothesise that survival away from the mysid host involves the utilisation of an intermediate host by an as yet undiscovered microniscus larva, as in other epicarideans. For the copepod, we considered the available evidence in support of a number of hypotheses. A new pattern of behaviour, unique within the copepod family Nicothoidae, was discovered in N. rahotsu. After the infective female copepodid stage attached to the host, it moulted into an immature female and penetrated the host tissue. It then migrated internally, typically through the dorsal trunk musculature of the host, finally emerging into the host marsupium. This behaviour was observed exclusively during the season when copepods occurred within the marsupium. We inferred that this internal migration behaviour in some ways facilitates the synchronisation of the parasite life cycle with the oviposition by the host into the marsupium. It remains uncertain how and where $N$. rahotsu passes the exclusive occurence of $P$. curviabdominalis.
\end{abstract}

KEY WORDS: Copepod $\cdot$ Isopod $\cdot$ Mysid $\cdot$ Parasite $\cdot$ Host $\cdot$ Antagonism $\cdot$ Competition

\section{INTRODUCTION}

Although symbiosis other than predation in marine plankton communities has been long recognised (e.g. Chatton \& Lwoff 1935, Sewell 1951, Ho \& Perkins 1985, Cachon \& Cachon 1987, Théodoridès 1989, Shields
1994, Ohtsuka et al. 2000), information remains rather fragmentary. A variety of symbiotic relationships (cf. Bush et al. 2001, Rhode 2005) has been reported from planktonic communities including: phoresy, commensalism, mutualism, parasitism and parasitoidism. Alveolate parasitioids such as apostome ciliates and 
dinoflagellates have been reported recently as causing mass mortality in host zooplankters (Ianora et al. 1987, Coats \& Heisler 1989, Kimmer \& McKinnon 1990, Gómez-Gutiérrez et al. 2003). Impacts on the host populations have been estimated in some cases. For example, Kimmer \& McKinnon (1990) showed that the host copepod mortality rate reached a maximum of $41 \% \mathrm{~d}^{-1}$ due to a parasitoid dinoflagellate. However, such interactions between planktonic organisms are poorly understood, partly because of the difficulty in making observations on such small organisms and in establishing experimental cultures of both hosts and parasites in the laboratory. Relationships between different symbionts that share a common host have rarely been studied, although complex antagonistic interactions have been demonstrated between larval trematodes infecting the same intermediate mollusc host (Kuris 1990, Sousa 1990, 1992, 1993).

We have intensively surveyed host-parasite relationships in marine pelagic ecosystems (Ohtsuka et al. 2000, 2003, 2004a,b, 2005, Horiguchi \& Ohtsuka 2001, Hanamura \& Ohtsuka 2003, Horiguchi et al. 2004, 2006, Shimomura et al. 2005, Harada et al. 2007). During these studies we discovered 2 crustacean parasites infecting the marsupium of the mysid Siriella okadai in the Seto Inland Sea, western Japan: the epicaridean isopod Prodajus curviabdominalis (Dajidae) and the siphonostomatoid copepod Neomysidion rahotsu (Nicothoidae). Both of these parasites utilise the lumen of the mysid marsupium as a microhabitat and its eggs (and embryos) as food (Ohtsuka et al. 2005, Shimomura et al. 2005). Single infections of mysids by dajids and nicothoids have been reported from all over the world (e.g. Hansen 1897, Gilson 1909, Pillai 1963, Schultz \& Allen 1982, Heron \& Damkaer 1986). However, as far as we are aware, a mysid host parasitised by 2 different marsupium-inhabiting parasite species has never been recorded. This study examines seasonality in the occurrence and interactions of these 2 parasites on the host and presents observations of a highly specialised, novel behaviour pattern displayed by the copepod. The possibility of an antagonistic interaction between these 2 parasites is also discussed.

\section{MATERIALS AND METHODS}

Field observations of seasonality in the $\mathbf{2}$ parasites. Specimens of the host mysid Siriella okadai were collected from the central part of the Seto Inland Sea, western Japan, near the Takehara Marine Science Station of Hiroshima University ( $\left.34^{\circ} 19.4^{\prime} \mathrm{N}, 132^{\circ} 55.4^{\prime} \mathrm{E}\right)$. Collections were carried out exclusively at night on a monthly basis from June 2003 to March 2005, by towing conical plankton nets (mesh size 0.1 or $0.3 \mathrm{~mm}$; dia- meter $30 \mathrm{~cm}$ ) obliquely from the breakwater of the station, because the mysids appear near the surface only after sunset. The mysids were fixed in $10 \%$ neutralised formalin/seawater immediately after capture. A minimum of 20 adult females of the mysid was sampled monthly to study the seasonal patterns of prevalence and the intensity of infection by 2 crustacean parasites, the isopod Prodajus curviabdominalis and the copepod Neomysidion rahotsu, both of which inhabit the mysid marsupium. All parasites, including the dwarf males of both species, were removed from the host marsupia using fine needles, and were identified and counted under dissecting and compound microscopes using the data of Shimomura et al. (2005) for the isopod and of Ohtsuka et al. (2005) for the copepod.

Water temperature and salinity were measured approximately monthly off the Takehara Marine Science Station, close to the sampling site, as the average of 2 readings, one taken at a depth of $1 \mathrm{~m}$ and the other $2 \mathrm{~m}$ above the sea bottom (total depth ca. $20 \mathrm{~m}$ ), using a CTD (ACT20-D, Alec Electronics).

Field observations of Neomysidion rahotsu excavating host tissue. A chance observation in late 2004 revealed the presence of immature females (but no males) of $N$. rahotsu deep within the tissues (cephalothorax and abdomen) of the host mysid. These were easily visible in live specimens of the host, but were very difficult to observe in fixed specimens due to the opaque bodies, and had been overlooked in earlier samples. From December 2004 to November 2005 collections of the host were made as described above, but observations were made on live host specimens under a binocular microscope before fixing. The presence or absence of the parasites in the host marsupium was also checked. Prevalence of immature females of $N$. rahotsu in the host tissues was calculated for 5 developmental stages of the host (juvenile; immature $\sigma^{\prime}$, ơ; mature $\sigma^{\prime \prime}$, o).

Some immature females of Neomysidion rahotsu were available in situ for histological observations using the paraffin-embedding method in order to reveal the extent of host damage caused by the parasite. The procedure was briefly as follows: fixation in $10 \%$ neutralised formalin/seawater, desalination with distilled water, dehydration through a graded ethanol series and immersion in xylene, paraffin-embedding, sectioning using a microtome and mounting on glass slides, double staining with haematoxylin-eosin, and mounting in balsam.

Laboratory observation of behaviour and life cycles of Neomysidion rahotsu and Prodajus curviabdominalis. Mysids parasitised by $N$. rahotsu were collected from the field in 2005 and isolated individually in deep Petri or evaporating dishes (ca. $50 \mathrm{ml}$ ) filled with filtered seawater, and incubated at water temperatures of $12.5 \pm$ $0.7^{\circ} \mathrm{C}$ in February, $15.0 \pm 0.7^{\circ} \mathrm{C}$ in May and June, and 
20.0 or $22.5 \pm 0.7^{\circ} \mathrm{C}$ in July and August in an incubator (LH-200-RDSCT, NK Systems). They were maintained for a maximum $43 \mathrm{~d}$ and fed Artemia nauplii every 1 to $2 \mathrm{~d}$, and the seawater was changed every 2 or $3 \mathrm{~d}$.

Numerous copepodids of Neomysidion rahotsu were released from the mysid marsupia and used in infection experiments to determine the life cycle and the duration of each developmental stage. Previously uninfected mysids were exposed to copepodids that developed into adults under experimental conditions. The numbers of host eggs and parasite egg sacs in the marsupium of each incubated host were counted daily. The production rate of egg sacs of the copepod was estimated for a mixture of fully mature female copepods without egg sacs and infective copepodids. The feeding rate of the copepod on host eggs was calculated by comparing numbers of host eggs at the beginning and at the end of the incubation period, using mature female mysids containing both their own eggs and an immature female of $N$. rahotsu in their marsupium.

Three females of Siriella okadai infected by Prodajus curviabdominalis were collected from the field in October and November 2004 and incubated at $20.0 \pm 0.7^{\circ} \mathrm{C}$ for $10 \mathrm{~d}$ as above. Brooding and hatching of the epicaridium larvae were documented by daily observations.

\section{RESULTS}

\section{Water temperature and salinity}

Water temperature varied seasonally from about $11^{\circ} \mathrm{C}$ in February and March to about $26^{\circ} \mathrm{C}$ in August and September, but without marked differences from year to year (Fig. 1). In contrast, salinity fluctuated year to year, ranging from a minimum of 30.9 PSU in November 2004 to a maximum of 33.6 PSU in April 2004, but showed a general tendency towards high values in winter and low values in summer and autumn (Fig. 1).

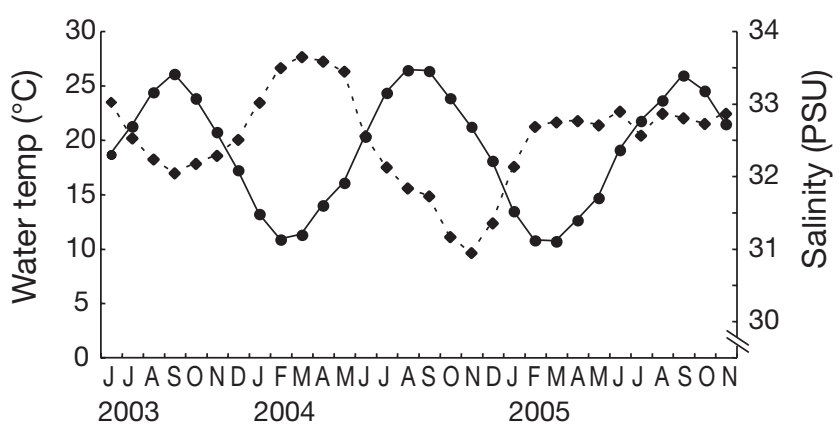

Fig. 1. Annual changes in water temperature ( $\bullet-)$ and salinity (----) from June 2003 to November 2005, at depths of $2 \mathrm{~m}$ above the sea bottom and at the sampling site in the Seto Inland Sea, Japan (average of these 2 sets of readings)

\section{Seasonal occurrence of 2 crustacean parasites}

Between June 2003 and November 2005 a total of 3146 adult females of the host mysid Siriella okadai were examined for the presence of 2 crustacean parasites Prodajus curviabdominalis (immature and mature females plus cryptoniscus larvae) and Neomysidion rahotsu (immature and mature females) in the lumen of the host marsupium. During this 30 mo period a distinct seasonal pattern in the prevalence of adult females of both of these parasites was found, although the intensity of infection per host by the adult females was always 1.0 in both species.

The occurrence of adult females of Prodajus curviabdominalis within the host marsupium was restricted to a period from mid-summer to late autumn, when water temperatures typically exceeded $20^{\circ} \mathrm{C}$. This period is hereafter referred to as the Prodajus-season. During the Prodajus-season the copepod Neomysidion rahotsu was almost totally absent from the host population. The prevalence rate of $P$. curviabdominalis differed significantly with temperature, with infections absent $(0.0 \%$ prevalence) below $20^{\circ} \mathrm{C}$ and $6.8 \%$ above $\left(\chi^{2}\right.$-test, $\mathrm{p}<$ 0.01 ). The monthly prevalence rate ranged from 0 to $19.0 \%$, with a peak in October or November of each year (19.0\% in October 2003; $11.5 \%$ in October 2004; $15.4 \%$ in November 2005). Mean prevalence for the 13 mo in which they were present on the host was $9.1 \%$. In the majority (105) of the 112 infections observed, females were accompanied by 1 , or rarely 2 , dwarf males.

In contrast, adult females of Neomysidion rahotsu occurred from mid-winter to summer (Fig. 2), which almost mirrored the pattern of presence of the isopod on the hosts. Over the entire sampling period, prevalence ranged from 0 to $18.2 \%$, with peaks in June 2003

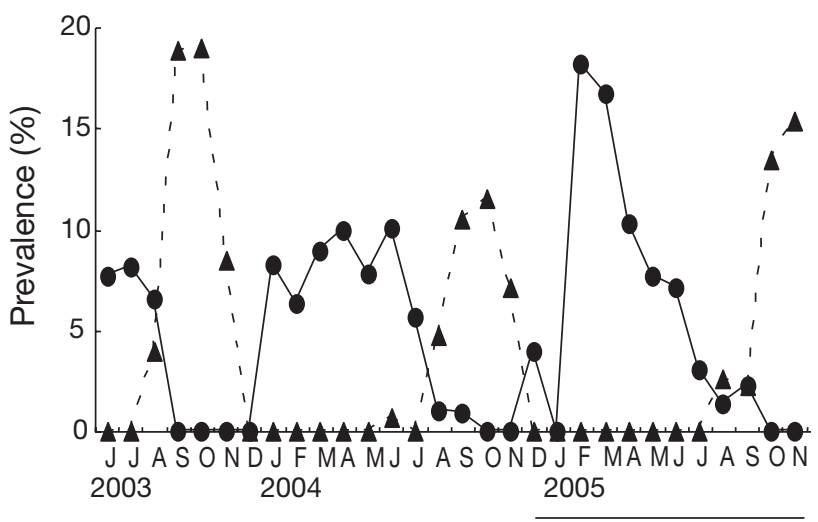

Fig. 2. Neomysidion rahotsu and Prodajus curviabdominalis. Annual changes in the prevalence of females of 2 crustacean parasites, copepod N. rahotsu $(-\bullet)$ and isopod P. curviabdominalis (-- --), on mature females of the host mysid Siriella okadai. The bar below months indicates the field observation period during which the prevalence of immature females of $N$. rahotsu excavating host tissue (see Fig. 5) was checked 
(8.1\%), June 2004 (10.1\%) and February 2005 (18.2\%). The prevalence of the copepods also differed significantly with temperature, with $3.0 \%$ above $20^{\circ} \mathrm{C}$ and $8.9 \%$ below $\left(\chi^{2}\right.$-test, $\left.p<0.01\right)$. During the study period, adult female copepods were totally absent from the host marsupia in October and November of each year from 2003 to 2005. The mean monthly prevalence for the 21 mo during which they occurred on the host was $7.2 \%$. The number of dwarf males attached to a female varied remarkably, from 1 to 23, with a mean of 1.3 female $^{-1}(\mathrm{~N}=136)$. The occurrence of dwarf males or copepodids only in the host marsupium, i.e. with no adult female present, was noted, but at relatively low frequency $(0.2$ to $1.6 \%)$ and only during a restricted period (April to June) each year.

Simultaneous infections by these 2 crustacean parasites were extremely rare. In only 2 cases of 136 infections by female copepods were double infections recorded. The details of these 2 double infections were: (1) a developing female copepod and a cryptoniscus larva of the isopod co-occurred in August 2003 and (2) a fully mature female copepod and a metamorphosing immature female of the isopod co-occurred in September 2004. It is noteworthy that both cases were combinations of an immature/mature stage of the copepod with a larval/immature stage of the isopod, respectively. A comparison between expected and observed double infections by these 2 parasites is made to detect any possible antagonism between them. The expectation of double infection is calculated as follows: $(136 / 3146 \times$ $112 / 3146)=1.539 \times 10^{-3}$. This would generate an expected 4.84 cases of double infection for the sample size of 3146 hosts. However, we found only 2 cases in the 3146 female hosts examined, in neither of which was a combination of an adult copepod and an adult isopod found. The null hypothesis (infection of the 2 parasites within a host marsupium occurs independently without any interspecific interference) cannot be discarded (probability function of Poisson distribution, $\mathrm{p}>0.05$ ), but the latter difference ( 0 vs. 4.84 ) is significant ( $p<$ 0.01 ), suggesting an antagonistic relationship between adults of the 2 parasites (see below). In addition, we performed the same calculation for only the months when both parasites actually co-occurred: August 2003, June, August and September 2004, and August and September 2005. The probability of double infection is: $(62 / 1530$ $\times 64 / 1530)=1.695 \times 10^{-3}$, giving an expected value of 2.59 cases. In this case the differences ( 2 vs. 2.59; 0 vs. 2.59) are not significant ( $p>0.05)$.

\section{Behaviour and life cycle of Neomysidion rahotsu}

The infective copepodid has a body length of about $0.17 \mathrm{~mm}$ (Ohtsuka et al. 2005) and hatches directly from an egg as in other nicothoid copepods, with no intervening nauplius phase (cf. Hansen 1897, Heron \& Damkaer 1986, Ohtsuka et al. 2005). Sexual differences in the behaviour of $N$. rahotsu copepodids were noted at this stage. Male copepodids directly entered the host marsupium and attached themselves to its inner surface by means of a frontal filament (Fig. 3b), which appears at the post-copepodid moult. This was not previously observed by Ohtsuka et al. (2005). It took about $7 \mathrm{~h}$ from first entering the host marsupium for the cephalothorax of an exposed male copepodid to become laterally expanded. In copepodids at an advanced state of development just before moulting, the adult male was visible through the translucent cuticle within the expanded cephalothorax of the attached copepodid (Fig. 3a). We infer, therefore, that the male side of the life cycle is highly abbreviated, with the number of stages possibly being as low as 2 (copepodid and adult).

In contrast, female copepodids attached to the surface of the host in the abdominal region or elsewhere (Fig. 4a) and then moulted into a stage referred to here as the young female (Fig. 4b). Within the exuvium of the copepodid, a thin membranous structure was observed (Fig. 4b), which may represent a transient 'pupal' stage, sensu Hansen (1897), that has been passed through during the moult from copepodid. The young female (Fig. $4 \mathrm{c}$ to e) is about $0.15 \mathrm{~mm}$ in length, dorso-ventrally depressed, and the cephalothorax is similar to that of a fully mature female, but with a much less developed trunk (cf. Ohtsuka et al. 2005, their Fig. 1). The trunk appears highly flexible (Fig. 4e). The young females penetrated into the host musculature, perhaps using their well-developed mouthparts (see Ohtsuka et al. 2005, their Fig. 4C,D), and we infer that they feed on the surrounding host tissues because histological sectioning shows a cavity
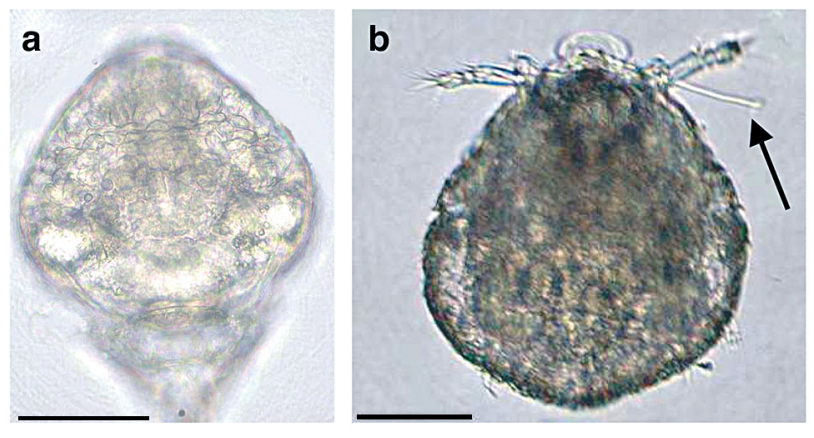

Fig. 3. Neomysidion rahotsu. (a) Copepodid from host marsupium with an expanded cephalothorax within which a male with numerous knobs present dorsally on the cephalothorax (see Ohtsuka et al. 2005) is visible; (b) immature male with a frontal filament (arrowed), removed from host marsupium. Scale bars: $0.05 \mathrm{~mm}$ 

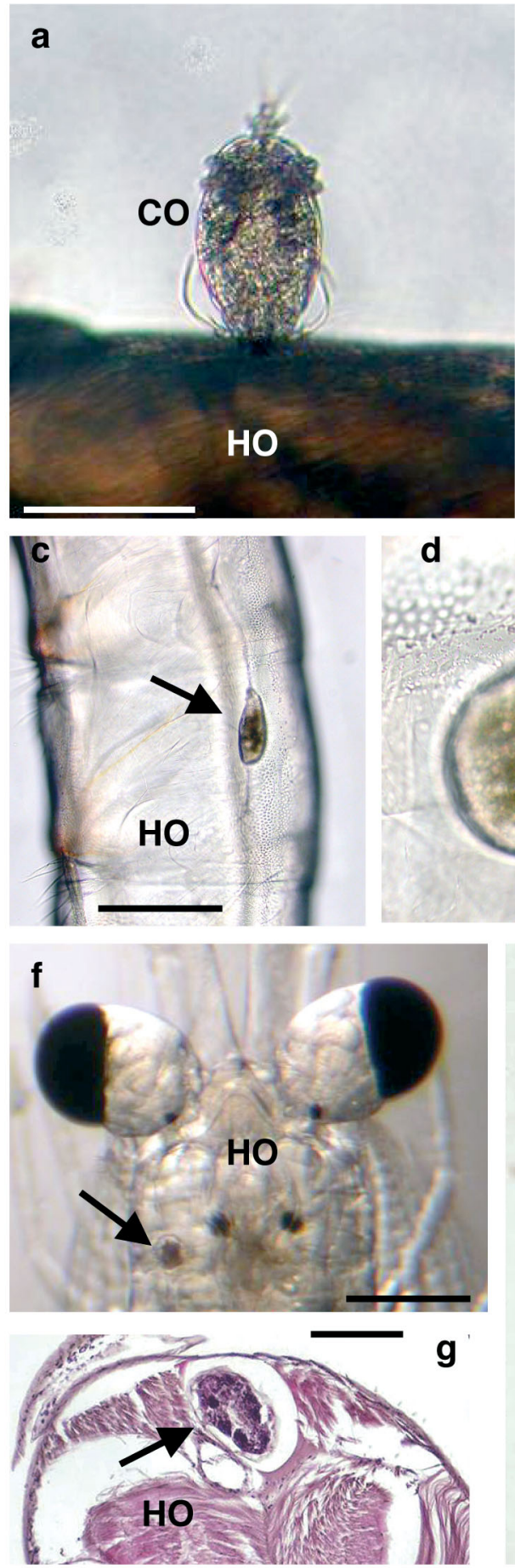

d
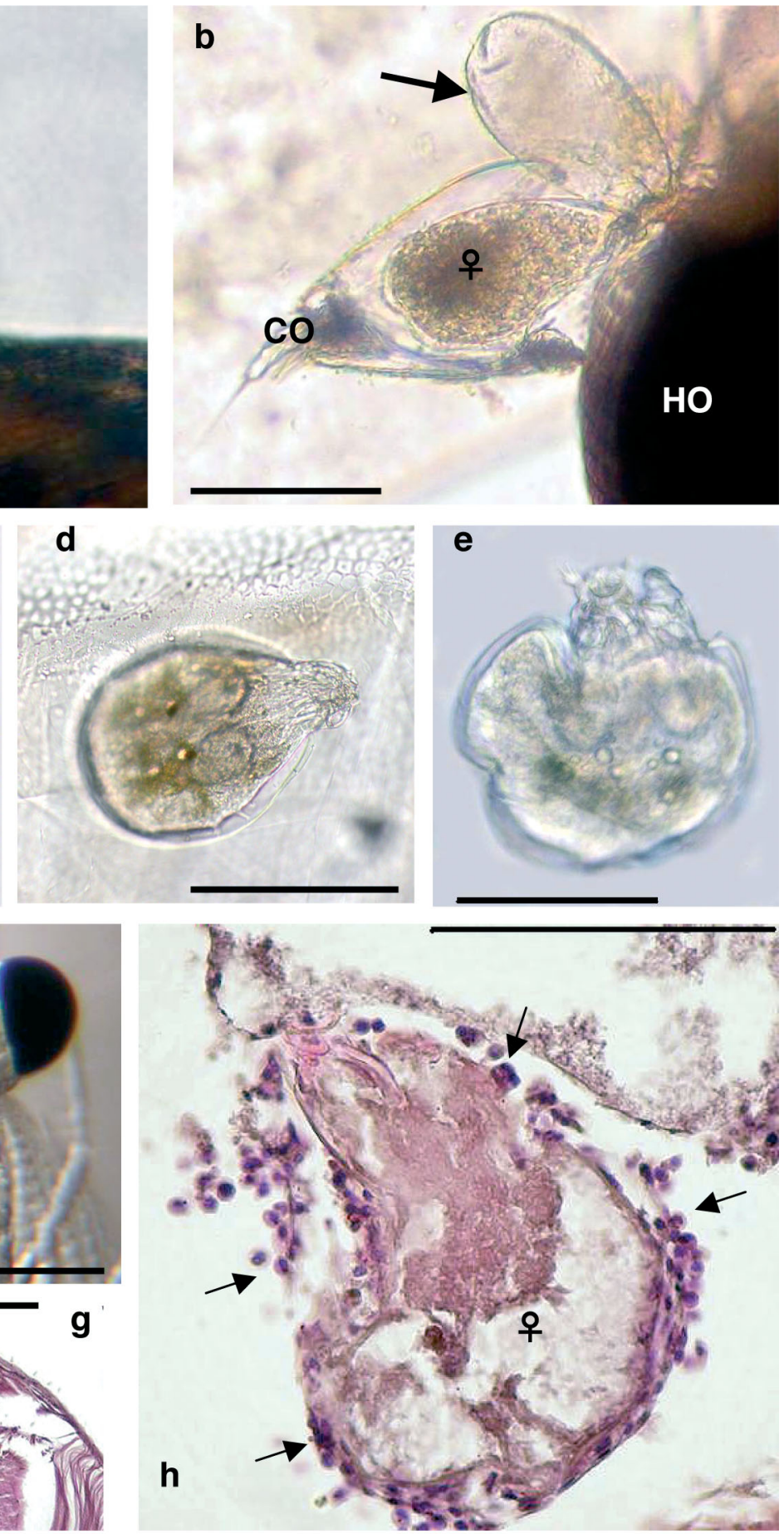

Fig. 4. Neomysidion rahotsu. (a) Copepodid attached to outer body surface of Siriella okadai; (b) penetration of immature female (o) into host just after moulting, exuvium of possible 'pupal' stage arrowed; (c) immature female (arrowed) migrating within abdomen of host; (d) immature female in situ within host; (e) immature female removed from host, showing flexible trunk cuticle; (f) immature female (arrowed) located near ovary of host; (g) transverse section through posterior thorax of parasitised host showing an immature female copepod (arrowed) located within cavity; (h) section through immature female (o) within host, note numerous host haemocytes (arrowed). CO: copepodid; HO: host. Scale bars: $0.1 \mathrm{~mm}(\mathrm{a}, \mathrm{b}, \mathrm{d}, \mathrm{e}, \mathrm{g}, \mathrm{h}) ; 0.2 \mathrm{~mm}(\mathrm{c}, \mathrm{f})$ 
around the female (Fig. 4g) that appears to have been excavated by the female. In some cases penetrating females are surrounded by host haemocytes (Fig. 4h), which may indicate some kind of response to the presence of the parasite. Excavating females migrate anteriorly within the host, towards the host's ovary (Fig. 4f), and finally appeared within the marsupium. We did not observe how the female emerged from the host into the marsupium. Once in the marsupium, the female copepod began consuming host eggs, and the trunk underwent extreme expansion and modification (cf. Ohtsuka et al. 2005, their Fig. 2). The number of stages on the female side of the life cycle was not determined precisely, but there are probably three if the transient pupal stage is included. The expansion and modification of the trunk after feeding that commenced within the marsupium was remarkable, but we have no evidence of any accompanying moult.

In the laboratory, it took a mean of $4.2 \mathrm{~d}$ (range 3 to $5 \mathrm{~d}, \mathrm{~N}=5$ ) from attachment of the copepodid to the start of excavation into the host tissue by the immature female, irrespective of water temperature. The duration of this excavation behaviour varied from about 3 to $43 \mathrm{~d}$. The emergence of the immature female copepods from the host tissue into the marsupium appeared to coincide with oviposition by the host mysid. A single immature female copepod, which infected an immature male host, remained inside the host tissues, but showed no morphological changes for $38 \mathrm{~d}$. It disappeared from the host on the 39th day.

The feeding rate of a female copepod was observed at 6 to 10 eggs $\mathrm{d}^{-1}$ (mean $7.8, \mathrm{~N}=4$ ) at 12.5 to $22.5^{\circ} \mathrm{C}$. The production rate of egg sacs by female copepods ranged from 2 to $6 \mathrm{~d}^{-1}$ (mean 4.0, $\mathrm{N}=4$ ), and the development time from laying to hatching of copepodids was about $10 \mathrm{~d}$ at $15^{\circ} \mathrm{C}$ and about $7 \mathrm{~d}$ at $22.5^{\circ} \mathrm{C}$. The number of eggs of uninfected females (April to November 2005) per marsupium ranged from 8 to 31 (average $13.6, N=19$ ), so an entire brood of host eggs could be consumed by a copepod within about $4 \mathrm{~d}$.

In summary, the minimum life span of a female Neomysidion rahotsu can be estimated at about $13 \mathrm{~d}$ : $($ from egg to copepodid hatching $=7 \mathrm{~d})+($ copepodid $=$ $<1 \mathrm{~d})+($ excavation $=3 \mathrm{~d})+($ maturation and oviposition after feeding on host eggs $=3 \mathrm{~d}$ ).

\section{Seasonal variation in occurrence of excavating immature female Neomysidion rahotsu}

The occurrence of immature females of $N$. rahotsu excavating host tissue clearly showed a seasonal pattern (Fig. 5). Over 1000 juveniles of Siriella okadai (N =

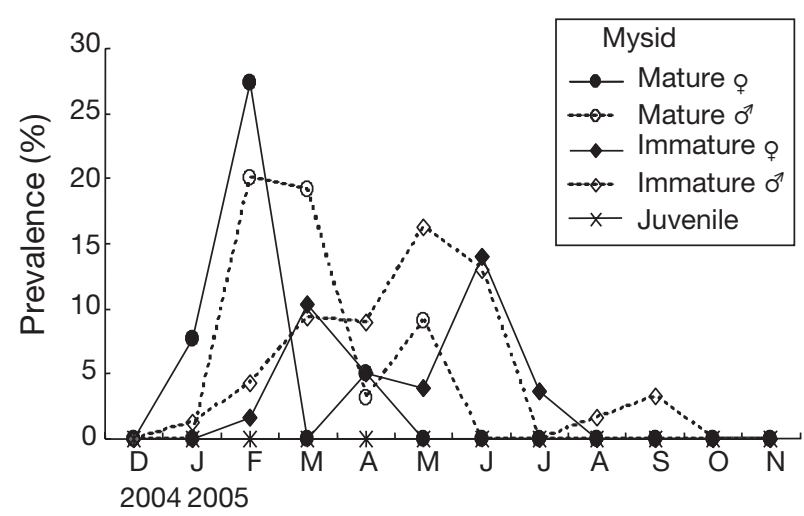

Fig. 5. Neomysidion rahotsu. Annual changes in the incidence of young females of $N$. rahotsu within the internal tissues of the host mysid Siriella okadai from December 2004 to November 2005. Host mysids were classified into 5 developmental groups (juveniles, immature $\wp$ and $\sigma^{7}$, mature $\rho$ and $\sigma^{7}$ )

1070) were investigated through the study period, but none was infected by the copepod. Infection rates differed considerably between mature and immature hosts. Mature hosts were parasitised by copepods from January to June 2005, with the highest prevalence in February $(27.8 \%$ for females $[\mathrm{N}=380], 20.0 \%$ for males $[\mathrm{N}=264])$. In contrast, immature females $(\mathrm{N}=$ $714)$ and males $(\mathrm{N}=815)$ were infected from February to September, with the highest prevalence in May $(16.3 \%)$ and June $(14.0 \%)$, respectively.

Intensity of immature females was invariably 1.0, in every host specimen examined. In addition, double infection with an immature female in the host body and a female within the host marsupium was never observed. Hence, the total prevalence of females on the host can be calculated from that of immature females in the host body plus that of females within the host marsupium (Figs. 2 \& 5), and it ranged from 0 (October, November 2005) to 45.5 (February 2005). Since competition between the copepod and the isopod occurred only within the host marsupium, prevalence of the copepods was shown separately in Figs. 2 \& 5 .

\section{Behaviour and life cycle of Prodajus curviabdominalis}

Oviposition and hatching of epicaridium larvae were observed for 3 parasitised female hosts (Fig. 6). Hatching of larvae commenced 5 to $8 \mathrm{~d}$ (mean $6.8, \mathrm{~N}=4$ ) after eggs were clearly visible inside the body of the female $P$. curviabdominalis. One female produced 2 broods of eggs during a $19 \mathrm{~d}$ observation period. In 1 female parasite, spawning started soon after the release of a batch of epicaridium larvae. 


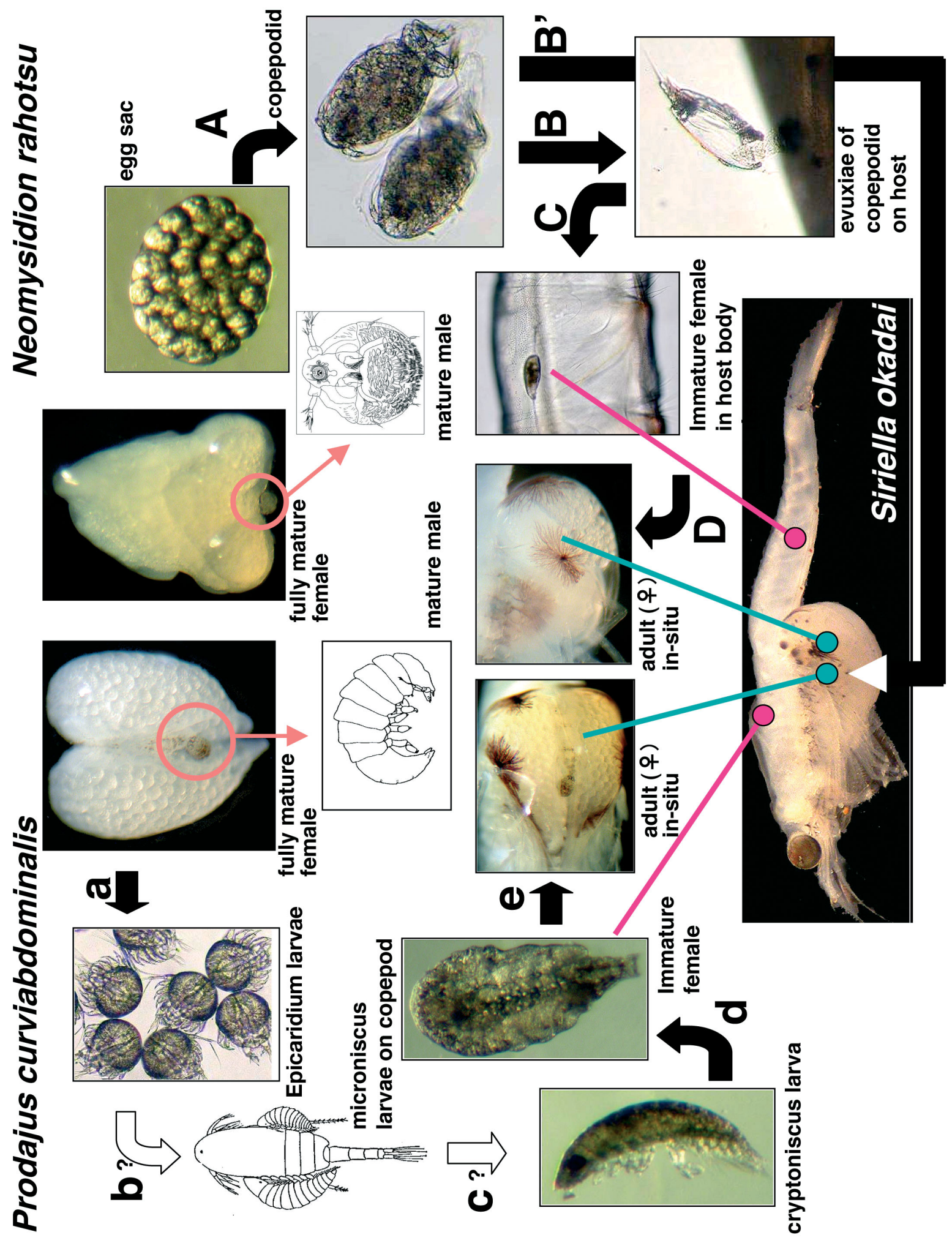

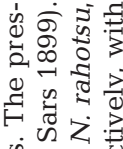

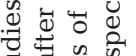

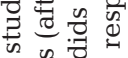

궁요

势.

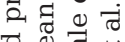

वृ 묘

늠 ⿹ㅠㅁ 믈

g $₫$

월 월

(ن)

원워

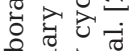

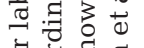

$\exists$ के

व

ठ

id

ช. ¿

t 0

สิ

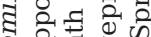

के जे

च

त्व

응

2.

드믈

$\widehat{\triangle}{ }_{\sigma}^{2}$

영묘

论

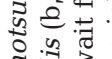

젼

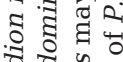

: 0.07

ฐ

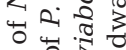

\&ै

ồ

$\bigoplus$ 品

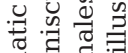

뭉

记品全

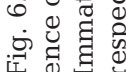




\section{DISCUSSION}

\section{Life cycles of Neomysidion rahotus and Prodajus curviabdominalis}

The life cycles of the isopod P. curviabdominalis and the copepod N. rahotsu on their mysid hosts were only partly elucidated in the preliminary studies by Shimomura et al. (2005) and Ohtsuka et al. (2005). By comparison with studies on related taxa, we can infer that some stages are still unknown (cf. Hansen 1897, Shiino 1964, Bowman \& Kornicker 1967, Heron \& Damkaer 1986, Rhode 2005).

All developmental stages are known for Prodajus curviabdominalis except for the microniscus larvae. The eggs are protected within the body of the female and hatch as epicaridium larvae, which are released from the female and swim freely in the water column. Cryptoniscus larvae were found attached to the body surface of the host (Shimomura et al. 2005), but no microniscus larva has yet been found. As in other epicarideans, the life cycle probably includes a microniscus larva prior to the cryptoniscus, and it may well utilise planktonic copepods as hosts (e.g. Shiino 1964, Anderson \& Dale 1981). These larval stages appear to live for about 6 to 7 mo during winter to early summer. After attachment of the cryptoniscus to the host, the female moults at least 3 times before becoming fully mature, although at least 5 post-cryptoniscus stages can be distinguished (Shimomura et al. 2005). When the cryptoniscus attaches to an immature female mysid without a fully developed marsupium, it waits beneath the host's carapace until the host reaches maturity (Shimomura et al. 2005). Although the longevity of the female isopod on the host and the number of broods produced during a female's reproductive lifetime are still unknown, 3 young females were maintained alive in the laboratory for $19 \mathrm{~d}$ and successfully bred.

The hypothetical life cycle of Neomysidion rahotsu proposed below is based on both published and newly presented data. Egg sacs which contain between 9 and 71 eggs are produced by the female within the host marsupium (Ohtsuka et al. 2005). The maximum number of egg sacs found within a single host marsupium was 28 , but the exact number of egg sacs a female can produce throughout her reproductive life is unknown. The single copepodid stage (this is a male based on our present study) hatches directly from the egg and emerges from the host marsupium. It is the infective stage and commences searching for a new host (Ohtsuka et al. 2005). The sex of a copepodid cannot be discerned morphologically, but must already be determined as different sex copepodids exhibit different behaviour patterns. A male copepodid enters the host marsupium and moults directly into an adult. These adult males attach themselves to the inner wall of the host marsupium by means of a, presumably temporary, frontal filament. In females, the exact number of moults is unknown. About 3 to $5 \mathrm{~d}$ after their release from the host, female copepodids locate a host and attach themselves to its body surface, where they metamorphose into young females. The young females penetrate the host tissues and commence feeding. They migrate within the host, eventually appearing within host marsupia at a time that coincides with release of host eggs into the marsupium. This synchronicity was confirmed 3 times in laboratory experiments. After the emergence of a female parasite into the marsupium it consumes 7 to 10 host eggs $\mathrm{d}^{-1}$. An average brood of host eggs can thus be consumed by a female copepod within about $4 \mathrm{~d}$.

The internal migration by which the young female Neomysidion rahotsu passes from the initial site of attachment onto the external body surface of the host into the marsupium is unique. Nothing like this has previously been reported for the Nicothoidae. Other nicothoid females that infect mysid marsupia develop into adults via 2 or 3 pupal stages, which are attached by frontal filaments inside this protected microhabitat (Hansen 1897, Heron \& Damkaer 1986). It is likely that $N$. rahotsu females lack free pupal stages. The cephalothorax of young females found in the host is the same as in fully mature females found within the marsupium, suggesting that these correspond to immature adults rather than pupal stages. We infer from the presence of a thin membranous structure within the copepodid exuvium (see Fig. 4b) that one transient pupal stage may be passed through as a double moult as the copepodid enters the host.

The host tissue excavation behaviour shown by females appears to be related to early attachment, either to immature hosts without developed marsupia, or to mature hosts without fully developed ovaries. So this stage could be interpreted as a holding stage which allows parasites to survive until the host mysids have developed marsupia and are ready to lay eggs. However, the host selection mechanism of the copepodids seems to lack sufficient fine-scale resolution to allow them to distinguish between the various stages and sexes of the host. Our observation of the eventual failure of development of a young female copepod that penetrated a male host is an evidence of poor resolution in host selection. This holding behaviour of female Neomysidion rahotsu is similar to that observed for the isopod Prodajus curviabdominalis, which waits beneath the host carapace until the host attains maturity (Shimomura et al. 2005). To egg-eating parasites that infect brood chambers, such as the peracarid marsupium, the benefits of behaviour which delays arrival until the host matures and the food source becomes available are obvious. 
It is noteworthy that double infection, with a female copepod in the body and another within the marsupium, was never observed. Since intensity of female copepods within the marsupium was exclusively 1.0, excavating females might appear within the marsupial lumen after the death of the indigenous inhabitant or be excluded by it. In contrast, excavating females in immature female hosts could succeed in colonising the host marsupium. The colonisation of those in the mature and immature male hosts must be finally unsuccessful after survival in the body for a period based on our laboratory experiments.

It takes a minimum of about $13 \mathrm{~d}$ to complete the life cycle from egg, via the tissue-penetrating stage, to mature female in the warm season. We estimate that there could theoretically be up to 20 generations per year, but host dynamics would limit this.

\section{Survival of Neomysidion rahotsu during the Prodajus-season}

The alternation between the 2 parasites occupying the same microhabitat on their mysid host appears to occur around the temperature threshold of $20^{\circ} \mathrm{C}$, throughout the 30 mo sampling period. The copepods re-established a population on the hosts almost immediately after the isopods disappeared. But, in contrast to the life cycle of the epicaridean isopod, the nicothoid copepod has no intermediate host (cf. Hansen 1897, Boxshall \& Halsey 2004) that might serve as an infection reservoir from which it can re-establish itself on the mysid. The hypothetical life cycles proposed here generate a key question: How is the population of $N$. rahotsu sustained during the 3 to 4 mo period of the Prodajus-season when adult females of $N$. rahotsu are apparently absent from the host population? Five possible scenarios can be envisaged:

(1) Dormancy outside of the host. We regard this as unlikely, since dormancy has not hitherto been reported for any species or any life cycle stages of members of the copepod order Siphonostomatoida (Dahms 1995, Ban 1998).

(2) Invasion of internal host tissues. The unique tissue penetration and internal migration behaviour exhibited by Neomysidion rahotsu is shown only by the female and is restricted to seasons when adults already occur within the host marsupium. It does not therefore appear to provide a mechanism for surviving the Prodajus-season.

(3) Host switching. We examined mature adult females of the 2 other dominant mysids in addition to the typical host Siriella okadai. Totals of 357 Anisomysis ijimai (22 October and 8 November 2004) and 161 Lycomysis bispina (17 January 2004) were collected near the sampling site in the Seto Inland Sea (Harada 2005). Harada (2005) found that only Prodajus species parasitised these mysids (prevalence rates 2.0 and $8.1 \%$, respectively). No copepods infected them. The A. ijimai were collected during October and November, i.e. the Prodajus-season, when P. curviabdominalis was found on S. okadai and N. rahotsu was absent. The sample size is not large, but the absence of $N$. rahotsu provides no evidence in support of the host-switching hypothesis. Since mysid diversity locally is high, with Paracanthomysis hispida and another unidentified species as well as these 3 occurring at the sampling site (S. Ohtsuka unpubl. data), the possibility of switching to a reservoir host remains.

(4) Prolongation of the pelagic stage (copepodid). The copepodid stage of Neomysidion rahotsu has well-developed mouthparts (see Ohtsuka et al. 2005, their Figs. $9 \& 10$ ) and usually attaches to the host within a day after hatching. The limited yolk reserves of the copepodid would be inadequate for an extended pelagic phase. For the copepodid to survive in the plankton for approximately 4 mo (during the Prodajus-season), it would be necessary for it to exploit an alternative food source. Information on the survivorship of infective copepodids of other siphonostomatoid copepods indicates that copepodids of species parasitic on fish typically must locate a new host within 3 to $4 \mathrm{~d}$ after hatching (Shotter 1971, Lin \& Ho 1993); failure to do so results in death. There is no evidence that the copepodid of $N$. rahotsu is able to utilise other food sources to extend the duration of its pelagic phase.

(5) Survival of parasite population in a restricted part of the host range. It is possible that the copepod survives at a low prevalence level on Siriella in some parts of the Siriella range, e.g. in deeper and colder waters. Many parasitic copepods overwinter at very low prevalence levels (usually as fertilised females), and these produce the first generation of larvae in the spring.

\section{Relationship between the 2 parasites}

The almost total absence of Neomysidion rahotsu during the Prodajus-season could be considered to be a co-evolutionary end point, since temporal partitioning of the niche of 'marsupium parasite' appears to be firmly established. The most likely selection pressure driving this relationship may well have been severe predation of the isopod upon the copepod. It seems highly likely that the larger isopod could feed upon the copepod and its egg sacs, which lie within the marsupium of the host and are similar in size to host eggs. However, given the temporal partitioning in usage 
of the marsupium, we were unable to observe direct predation.

The co-evolutionary relationships between the mix of parasite species exploiting the same host are poorly understood in comparison with those between hosts and parasites (cf. Moore 2002). Antagonism between co-existing parasites has been documented for mixed species of larval trematodes infecting intermediate gastropod hosts (e.g. Lie et al. 1968, Kuris 1990, Sousa 1990, 1992, 1993, Urabe 2004). Although statistical support is weak, the present study could correspond to direct (predatory) or negative indirect (non-predatory) antagonistic interactions (cf. Lie et al. 1968, Sousa 1992) between 2 parasites competing for the same space and the same food resource from the host. As Sousa $(1990,1993)$ pointed out for antagonistic interactions between larvae of co-occurring digenean trematodes on intermediate host snails, both the existence of hierarchical antagonism and hierarchical species replacement are recognisable for the present interactions between Neomysidion rahotsu and Prodajus curviabdominalis. In this case, the dominant parasite would be $P$. curviabdominalis, and the subordinate would be $N$. rahotsu. The dominance of $P$. curviabdominalis may be a consequence of its larger size, more active immature stages and, possibly, greater raptorial ability than $N$. rahotsu. Of course, this dominance must have been established through complicated co-evolutionary processes among the host and both parasites. Such antagonism between the parasites might have developed from exploitation competition to interference competition, as Kuris (1990) suggested. If, for N. rahotsu, avoidance of predation by Prodajus has been the main driver resulting in this system of alternating occupancy of the host's marsupium, the key question is: What kind of trigger maintains the precise timing of the life cycle of the copepod? One possibility is that the copepod detects some chemical cue released from an isopod occupying the mysid.

On the other hand, habitat segregation or different site specificities have commonly been reported between co-occurring species of fish gill parasites, such as monogeneans (Ramasamy et al. 1985) and ergasilid copepods (Ho \& Do 1982). Such segregation may be found between small parasites on a relatively largesized host, such as a fish. The host provides a wide variety of microhabitats and food sources that can be exploited differentially by different parasites, leading to segregation rather than interference or competition. In contrast, interference or competition between coexisting parasites may occur in small-sized hosts, such as mysids and snails, given the more restricted habitat and food resources available, as Sousa (1993) has pointed out.

\section{Impact of the parasites on the mysid host}

Generally it is difficult to estimate the impacts of parasites on individuals and populations of invertebrate hosts in aquatic ecosystems, mainly because basic physiological and ecological characteristics of both organisms are rarely known. In this case, the generation time, growth rate and feeding rate of the host mysid and of the 2 crustacean parasites are poorly known. But we can infer some of the impacts of these parasites on the host mysid at the level of the individual and the population.

Nicothoid copepods are reported to inhibit ovulation, maturation and growth of their host crustaceans (Hansen 1897, Daly \& Damkaer 1986). Within the family Nicothoidae, Neomysidion rahotsu is unique in that young females negatively impact all stages of the host, except for juveniles, by their tissue excavation behaviour. This endoparasitic stage feeds on host tissues, mainly muscle, which will adversely affect the swimming, feeding and growth of the host. The penetration of the endoparasitic stage and its eventual exit from the host will also cause lesions in the cuticular exoskeleton of the host, with consequent adverse affects. This unique internal migration by young females takes place within the dorsal trunk musculature and does not appear to interfere with the development of host ovaries and, thus, will not reduce host egg output. Within the host marsupium, the female feeds voraciously upon host eggs at a rate of 7 to 10 eggs female ${ }^{-1}$ $\mathrm{d}^{-1}$, and a brood of host eggs could be consumed by a copepod female within just a few days. However, the next host brood seems to be suppressed by the presence (the egg mimicry?) of the parasite. The egg sacs of the copepod are similar to individual host eggs in size and shape, and, while they are present within the host marsupium, the host females seem to pause in their egg production. It is uncertain whether broods of the mysid are always suppressed by the presence of a mature parasitic copepod within the marsupium. Mature female mysids newly lay eggs into an empty marsupium after moulting and subsequent copulation with males (Mauchline 1980). Therefore, if the parasitism by either a copepod or an isopod within the marsupium inhibits moulting of the host, the subsequent oviposition would be suppressed. One brood of eggs of the host may be the first and last meal for a mature female of the copepod and the isopod.

In the Columbia River estuary, Daly \& Damkaer (1986) found that an average of $37 \%$ of eggs of the mysid Neomysis mercedis was lost by feeding of the nicothoid copepod Hansenulus trebax, although prevalence was extremely high, reaching $53 \%$ on average. Since Daly \& Damkaer (1986) also observed consumption of an entire brood of host eggs by a large 
female copepod within a marsupium, total loss of eggs in the host population may reach a value nearly as high as average prevalence. In Neomysidion rahotsu mean prevalence was much lower, ca. $7.2 \%$, but loss of host eggs may reach a value as high as $7 \%$ when $N$. rahotsu occupies the host marsupium. Considering the estimated minimum generation time to be $13 \mathrm{~d}$, about $0.6 \%$ of total egg production within the mysid population could be lost daily to the parasite.

In contrast to Neomysidion rahotsu, only adult females of Prodajus curviabdominalis cause serious damage devouring host eggs. This infection exerts an adverse affect on the host population. No host eggs remained when a fully mature female isopod was present within the marsupium, suggesting that all eggs in a brood were consumed by the isopod. Mean prevalence of the isopod was about $9.1 \%$. In summary, the mysid may lose between 7 and $9 \%$ of its egg production per month due to infections by each of these 2 parasites, assuming that spawning of the host occurs throughout the year.

Acknowledgements. We express our sincere thanks to Dr. Kazuya Nagasawa for his encouragement throughout the present study. This study was partly supported by grants from the Japan Society of the Promotion for Sciences (Nos. 14560151, 18770076).

\section{LITERATURE CITED}

Anderson G, Dale WE (1981) Probopyrus pandalicola (Packard) (Isopoda, Epicaridea): morphology and development of larvae in culture. Crustaceana 41:143-161

Ban S (1998) Dormancy in Copepoda. Uni no Kenkyu 7:21-34 (in Japanese with English abstract)

Boxshall GA, Halsey SH (2004) An introduction to copepod diversity. The Ray Society, London

Bowman TE, Kornicker LS (1967) Two new crustaceans: the parasitic copepod Sphaeronellopsis monothrix (Choniostomatidae) and its myodocopid ostracod host Parasterope pollex (Cylindroleberidae) from the southern New England coast. Proc US Natl Mus 123:1-28

Bush AO, Fernández JC, Esch GW, Seed JR (eds) (2001) Parasitism. The diversity and ecology of animal parasites. Cambridge University Press, Cambridge

Cachon J, Cachon M (1987) The parasitic dinoflagellates. Bot Monogr 21:571-610

Chatton É, Lwoff A (1935) Les ciliés apostomes: morphologie, cytologie, éthologie, evolution, systématique. Arch Zool Exp Gén 59:1-475

Coats DW, Heisler JJ (1989) Spatial and temporal occurrence of the parasitic dinoflagellate Duboscquella cachoni and its tintinnine host Eutintinnus pectinis in Chesapeake Bay. Mar Biol 101:401-409

Dahms HU (1995) Dormancy in the Copepoda - an overview. Hydrobiologia 306:199-211

Daly KL, Damkaer DM (1986) Population dynamics and distribution of Neomysis mercedis and Alienacanthomysis marcopsis (Crustacea: Mysidacea) in relation to the parasitic copepod Hansenulus trebax in the Columbia River estuary. J Crustac Biol 6:840-857
Gilson G (1909) Prodajus ostendensis n. sp. étude monographique d'um épicaride parasite du Gastrosaccus spinifer Goes. Bull Sci Fr Belg 43:19-92

Gómez-Gutiérrez J, Peterson WT, Robertis AD, Brodeur RD (2003) Mass mortality of krill caused by parasitoid ciliates. Science 301:339

Hanamura Y, Ohtsuka S (2003) Occurrence of intersex individuals in the sergestid shrimp, Acetes sibogae, in Darwin Harbour, Northern Territory, Australia. Crustaceana 76: $749-754$

Hansen HJ (1897) The Choniostomatidae, a family of Copepoda, parasites on Crustacea Malacostraca. Høst \& Son, Copenhagen

Harada S (2005) Taxonomy and ecology of ectoparasites on mysids. MSc thesis, Hiroshima University

Harada A, Ohtsuka S, Horiguchi T (2007) Species of the parasitic genus Duboscquella are members of the enigmatic Marine Alveolate Group I. Protist 158:337-347

Heron GA, Damkaer DM (1986) A new nicothoid copepod parasitic on mysids from northwestern North America. J Crustac Biol 6:652-665

Ho JS, Do TT (1982) Two species of Ergasilidae (Copepoda: Poecilostomatoida) parasitic on the gills of Mugil cephalus Linnaeus (Pisces: Teleostei), with proposition of a new genus Dermoergasilus. Hydrobiologia 89:247-252

Ho JS, Perkins PS (1985) Symbionts of marine Copepoda: an overview. Bull Mar Sci 37:586-598

Horiguchi T, Ohtsuka S (2001) Oodinium inlandicum sp. nov. (Blastodiniales, Dinophyta), a new ectoparasitic dinoflagellate infecting a chaetognath, Sagitta crassa. Plankton Biol Ecol 48:85-95

Horiguchi T, Harada A, Ohtsuka S (2004) Taxonomic studies on parasitic dinoflagellates in Japan. Bull Plankton Soc Jpn 53:21-29 (in Japanese with English abstract)

Horiguchi T, Harada A, Ohtsuka S, Soh HY, Yoon YH (2006) First record of an ectoparasitic dinoflagellate, Oodinium inlandicum (Dinophyta) infecting a chaetognath, Sagitta crassa from the Korean coasts. Algae 19:201-205

Ianora A, Mazzocchi MG, Scotto di Carlo B (1987) Impact of parasitism and intersexuality on Mediterranean populations of Paracalanus parvus (Copepoda: Calanoida). Dis Aquat Org 3:29-36

Kimmerer WJ, McKinnon AD (1990) High mortality in a copepod population caused by a parasitic dinoflagellate. Mar Biol 107:449-452

Kuris A (1990) Guild structure of larval trematodes in molluscan hosts: prevalence, dominance and significance of competition. In: Esch G, Bush A, Aho J (eds) Parasite communities: patterns and processes. Chapman \& Hall, London, p 69-100

Lie KJ, Basch PF, Heyneman D (1968) Direct and indirect antagonism between Paryphostomum segregatum and Echinostoma paraensei in the snail Biomphalaria glabrata. Z Parasitenkd 31:101-107

Lin CL, Ho JS (1993) Life history of Caligus epidemicus Hewitt parasitic on tilapia (Oreochromis mossambicus) cultured in brackish water. In: Boxshall GA, Defaye D (eds) Pathogens of wild and farmed fish: sea lice. Ellis Horwood, Chichester, p 5-15

Mauchline J (1980) The biology of mysids and euphausiids. Adv Mar Biol 18:1-681

Moore J (2002) Parasites and the behavior of animals. Oxford University Press, Oxford

Ohtsuka S, Nagasawa K, Gejima K (2000) Review of parasites of marine zooplankton. Bull Plankton Soc Jpn 47:1-16 (in Japanese with English abstract)

Ohtsuka S, Horiguchi T, Hanamura Y, Nagasawa K, Suzaki T 
(2003) Intersex in the mysid Siriella japonica izuensis Ii: the possibility it is caused by infestation with parasites. Plankton Biol Ecol 50:65-70

Ohtsuka S, Hanamura Y, Nagasawa K, Horiguchi T, Suzaki T (2004a) First record of the occurrence of an ellobiopsid Thalassomyces marsupii Kane on a new host of hyperiid amphipod in Japanese waters. Plankton Biol Ecol 51:110-112

Ohtsuka S, Hora M, Suzaki T, Arikawa M, Omura G, Yamada K (2004b) Morphology and host-specificity of the apostome ciliate Vampyrophrya pelagica infecting pelagic copepods in the Seto Inland Sea, Japan. Mar Ecol Prog Ser 282:129-142

Ohtsuka S, Boxshall GA, Harada S (2005) A new genus and species of nicothoid copepod (Crustacea: Copepoda: Siphonostomatoida) parasitic on the mysid Siriella okadai Ii from off Japan. Syst Parasitol 62:65-81

Ohtsuka S, Hanamura Y, Harada S, Shimomura M (2006) Recent advances in studies of parasites on mysid crustaceans. Bull Plankton Soc Jpn 53:37-44 (in Japanese with English abstract)

Pillai NK (1963) Two new genera of parasitic isopods from Kerala. J Zool Soc India 15:66-72

Ramasamy P, Ramalingam K, Hanna REB, Halton DW (1985) Microhabitats of gill parasites (Monogenea and Copepoda) of teleosts (Scomberoides spp.). Int J Parasitol 15: 385-397

Rhode K (ed) (2005) Marine parasitology. CSIRO Publishing, Collingwood

Sars GO (1899) An account of the Crustacea of Norway with short descriptions and figures of all the species, Vol 2. Isopods. Bergen Museum, Bergen

Schultz GA, Allen DM (1982) Prodajus bigelowiensis, new

Editorial responsibility: Matthias Seaman (Assistant Editorin-Chief), Oldendorf/Luhe, Germany species (Isopoda, Epicaridea: Dajidae) parasite of Mysidopsis bigelowi (Mysidacea) from coastal New Jersey, with observations of infestation. J Crustac Biol 2:296-302

Sewell SRB (1951) The epibionts and parasites of the planktonic Copepoda of the Arabian Sea. John Murray Exped 9: 255-394

Shields JD (1994) The parasitic dinoflagellates of marine crustaceans. Ann Rev Fish Dis 4:241-271

Shiino S (1964) Animal phylogeny, Vol 7 (upper). Arthropoda. Nakayama Shoten, Tokyo

Shimomura M, Ohtsuka S, Naito K (2005) Prodajus curviabdominalis n. sp. (Isopoda: Epicaridea: Dajidae), an ectoparasite of mysid, with notes on morphological changes, behaviour and life-cycle. Syst Parasitol 60:39-57

Shotter RA (1971) The biology of Clavella uncinata (Muller) (Crustacea: Copepoda). Parasitology 63:419-430

Sousa WP (1990) Spatial scale and the processes structuring a guild of larval trematode parasites. In: Esch G, Bush A, Aho J (eds) Parasite communities: patterns and processes. Chapman \& Hall, London, p 41-67

Sousa WP (1992) Interspecific interactions among larval trematode parasites of freshwater and marine snails. Am Zool 32:583-592

Sousa WP (1993) Interspecific antagonism and species coexistence in a diverse guild of larval trematode parasites. Ecol Monogr 63:103-128

Théodoridès J (1989) Parasitology of marine zooplankton. Adv Mar Biol 25:117-177

Urabe M (2004) Battle between parasites in the body of freshwater gastropods. In: Nagasawa K (ed) Aquaparasitology in the field in Japan. Tokai University Press, Tokyo, p 41-54 (in Japanese)

Submitted: March 16, 2007; Accepted: June 8, 2007

Proofs received from author(s): October 9, 2007 